\title{
Xanthine Sensor Based on Xanthine Oxidase Immobilized in Poly ( $p$-Benzoquinone) Film
}

\author{
Gorou ARAI*, Shigeo TAKAHASHI and Iwao YASUMORI
}

Received February 8, 1993 ; Accepted April 12, 1993

\section{INTRODUCTION}

The redox centers of most oxidoreductases are electrically insulated by protein shells. Because of these shells, the enzymes cannot be oxidized or reduced at bare electrodes. Recently, electrochemical immobilization of enzymes in various conducting polymers on electrodes have been undertaken on purpose to achieve the direct electrochemical communication between the redox centers of enzymes and electrodes $^{1-3)}$. In the previous paper ${ }^{4}$ ), we reported immobilization of glucose oxidase in a conductive redox polymer, poly(p-benzoquinone) film (SQ film) where the polymer chain serves as an effective electron-transfer chain between the redox center (FAD/FADH 2 ) of the enzyme and an electrode material. In order to gain further understanding of electrical relationships between flavoproteins and the polymer chain, we attempted to immobilize xanthine oxidase (XOD), a flavoprotein, in the polymer film.

Department of Applied Chemistry, Faculty of Engineering, Kanagawa University, Rokkakubashi, Kanagawaku, Yokohama 221 Japan.

Key Words: Xanthine Sensor, Conductive Polymer, Modified Electrode
In this paper, we describe the direct communication between XOD and an electrode via the polymer chain in the presence of xanthine and/or hypoxanthine.

\section{EXPERIMENTAL}

The immobilization of XOD in the polymer film was performed by an electropolymerization of mercaptohydroquinone in the presence of the enzyme. The electropolymerization was accomplished at $0.5 \mathrm{~V}$ vs. Ag/AgCl for $2 \mathrm{~h}$ in a $1 \mathrm{~cm}^{3}$ phosphate buffer solution ( $\mathrm{pH} 7.3$ ) containing $0.5 \mathrm{mM}$ ( $1 \mathrm{M}=1 \operatorname{mol} \mathrm{dm}^{-3}$ ) mercaptohydroquinone, $0.127 \mathrm{mg}$ XOD ( buttermilk, $0.5 \mathrm{U} \mathrm{mg}^{-1}$, and $0.1 \mathrm{M} \mathrm{NaCl}$ using an Au-electroplated glassy carbon electrode (GCE, $3 \mathrm{~mm}$ diameter) as a substrate electrode. The resulting electrode( XOD-SQ-GCE) was, then, covered with a cellophane. Electrochemical measurements were performed at $20^{\circ} \mathrm{C}$ in an $\mathrm{N}_{2}$ atmosphere using a three-compartment cell equipped with the XOD-SQ-GCE working electrode, a Pt wire counter electrode, and an Ag/AgCl reference electrode. All sample solutions were prepared with distilled-deionized water. Hypoxanthine and xanthine were purchased from wako Chemical Co. and all other chemicals were of reagent grade. 


\section{RESULTS AND DISCUSSION}

When xanthine was added to a voltammetric test solution, the anodic peak potential( $\mathrm{E}_{\mathrm{p}}^{\mathrm{a}}$ ) based on the oxidation of SQ film was slightly shifted to positive and the anodic current at more positive potential range than $\mathrm{E}_{\mathrm{p}}^{\mathrm{a}}$ was apparently increased. The XOD-SQ-GCE showed a well-defined current response within 1 min after the successive addition of deaerated phosphate buffer solution $(\mathrm{pH} 7.3)$ at $0.3 \mathrm{~V}$.

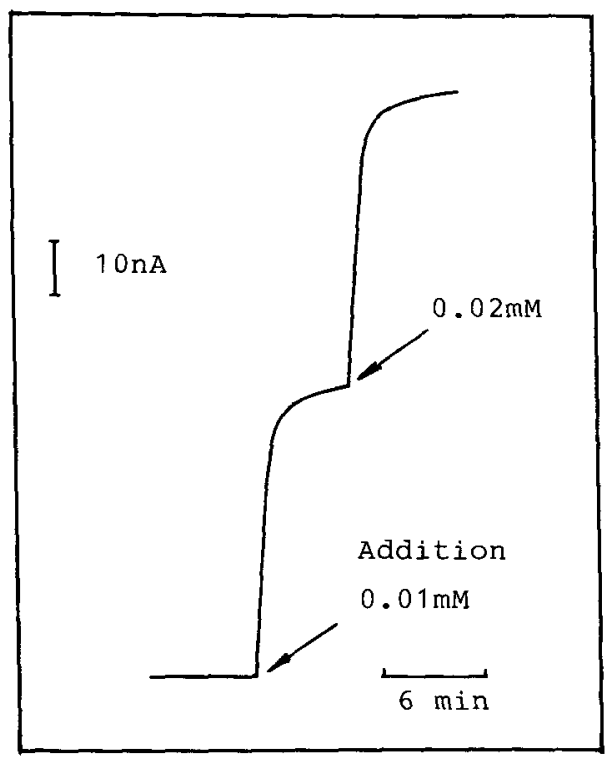

Fig. 1. Typical response of the XOD-SQ-GCE to addition of xanthine Each arrow répresents an increase in xanthine concentration.

This results show that the XOD immobilized in the polymer maintains its physiological activity and manifests that electron transfer may smoothly occur between the quinone moiety of the polymer chain and the redox active center in the enzyme.

Figure 2 shows the dependence of the steady-state current density on the concentration of xanthine and hypoxanthine at $0.3 \mathrm{~V}$. The current density was scarcely influenced by the presence of air in the test solution as shown in Fig. 2 .

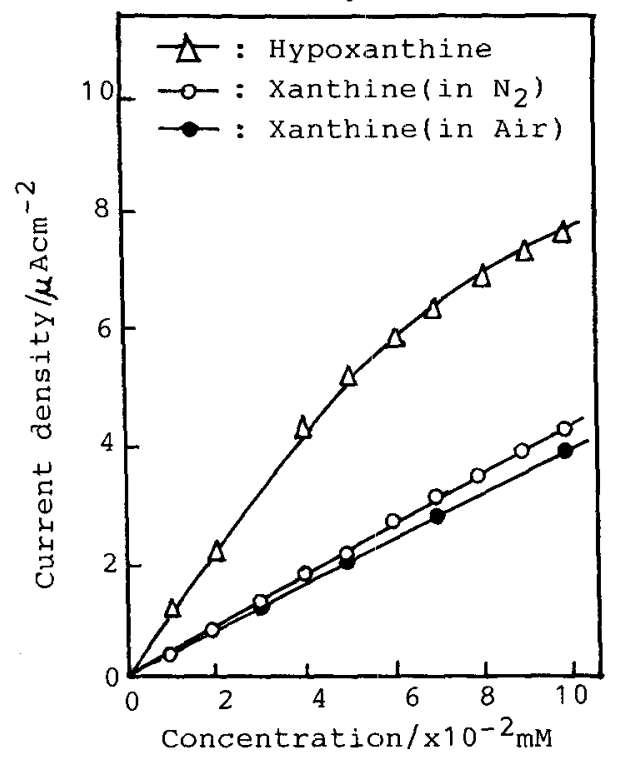

Fig. 2. Calibration curves of xanthine and hypoxanthine for the XOD-SQ-GCE

The response currents of the XOD-SQ-GCE showed an almost linear relationship up to $0.1 \mathrm{mM}$ for Xanthine and up to $0.05 \mathrm{~mm}$ for hypoxanthine. Thus, direct electron transfer between the enzyme active centers in XOD and a modified electrode surface has been achieved by the immobilization of the enzyme in the SQ film.

\section{REFERENCES}

1) S. Yabuki, H. Shinohara and M. Aizawa, J. Chem. Soc., Chem. Commun. 1989, 945.

2) P. T. Poet, S. Miyamoto, T. Murakami, J. Kimura and I. Karube, Anal. Chim. Acta, 235, 255 (1990).

3) B. A. Gregg and A. Heller, J. Phys. Chem., 95, 5976 (1991).

4) G. Arai, M. Masuda and I. Yasumori, Chem. Lett., 1992, 1791. 